\title{
Criteria for land suitability evaluation in a small catchment on the Loess Plateau in China
}

\author{
Ingmar Messing ${ }^{\mathrm{a}, *}$, Minh-Ha Hoang Fagerström ${ }^{\mathrm{a}}$, \\ Liding Chen ${ }^{\mathrm{b}}$, Bojie $\mathrm{Fu}^{\mathrm{b}}$ \\ ${ }^{\text {a }}$ Swedish University of Agricultural Sciences, Department of Soil Sciences, Box 7014, \\ SE-750 07 Uppsala, Sweden \\ ${ }^{\mathrm{b}}$ The Chinese Academy of Sciences, Research Center for Eco-Environmental Sciences, \\ Department of System Ecology, P.O. Box 2871, Beijing 100085, China
}

\begin{abstract}
This article describes some of the results of a land evaluation within the framework of a research project carried out in a small catchment on the Loess Plateau in northern China, which has long been exposed to land degradation from erosion. The project aimed to identify an approach for land use planning, combining participatory (land users) planning, land evaluation and soil erosion modelling. The results from this study were intended to provide the biophysical properties of importance to be used together with results from participatory approach (PA) studies and soil erosion modelling to construct scenarios for a more sustainable use of land. Land properties, which were restricting for agricultural cropping, were defined and values of each property were matched with the requirements for cropping. By defining the spatial distribution of critical properties, they could be combined to achieve compound suitability classes in each land unit for the chosen land use. Information was gathered from measurements and data searches as well as from farmers, using PA methods. Properties for which data and other information were available and which were considered to be relevant for the study included climate, soil water content, slope aspect, soil water storage capacity, rooting environment, tillage constraints, slope gradient, infiltration capacity, soil nutrients and flooding hazard. Each of the properties were discussed in relation to their influence on land suitability, primarily for agricultural crops. Whatever management changes were carried out to improve the productivity and sustainability in the project catchment, restrictions for agricultural production were large. The major constraints were water availability, nutrient availability and erosion hazard. The properties chosen for further use in suitability evaluation and scenario analyses were those having a significant spatial variability in the
\end{abstract}

* Corresponding author. Fax: +46-18672795.

E-mail address: Ingmar.Messing@mv.slu.se (I. Messing). 
catchment: soil type, slope gradient and slope aspect. The results from this study are applied in other articles this issue.

(C) 2003 Elsevier Science B.V. All rights reserved.

Keywords: Land characteristics; Land evaluation; Land properties; Land qualities; Loess Plateau of China

\section{Introduction}

Approaches to degradation control are changing in response to increasing expansion of degraded land and due to consistent difficulties in the performance of soil conservation programmes (Stocking and Lu, 2000). This article describes some of the results of a Work Package called Land Evaluation within the framework of a research project carried out in a small catchment on the Loess Plateau in northern China, which has been exposed to land degradation from erosion for a long time. The project was intended to identify an approach for land use planning, combining participatory (land users) planning, land evaluation and soil erosion modelling. The other work packages were field monitoring and land inventory, erosion model extension (LISEM), validation of the extended model and integrated participatory conservation planning.

We basically started from the concepts of A Framework for Land Evaluation (FAO, 1976). They are not strict instruction manuals, but indicate alternative ways of proceeding and it is intended that users should be selective in taking those elements which fit their needs, and to adapt them as required (Purnell, 1986). This qualitative approach for land evaluation was chosen, as compared to approaches using dynamic simulation models, since the latter ones require a host of accurate data on land and land use. There did not exist such data for the study catchment at the start of the project and, because the land evaluation part was to be applied at an early stage during the given period, the development and application of such a model was not feasible. Even if such a model could be constructed, after a vast input of measurements and tests, it would be doubtful whether the estimates generated would be sufficiently accurate for planners and decision makers (Driessen and Konijn, 1992). Instead, the qualitative land evaluation was combined with soil erosion modelling (using a dynamic computer model) and participatory approaches, in an iterative way, to construct acceptable scenarios for future land use changes. In short, using our qualitative approach, land qualities (compound properties) and land characteristics (properties which could be measured or calculated) which are restricting for a particular land use are defined, and values of each property are rated from no to severe restrictions. After defining the spatial distribution of values of critical properties on maps, the values are combined to achieve compound suitability classes in each land unit for a specific land use. Information was gathered from measurements and data searches, but also from farmers in the catchment by using rapid and participatory rural appraisal and other methods, here called participatory approach (PA) methods. Furthermore, the spatial distribution of values of properties was used together with results from PA studies and soil erosion modelling, to construct mapped scenarios of a more sustainable use of land (see Chen et al., 2003; Hessel et al., 2003). 
The results in the present study are to provide the biophysical properties of importance in suitability evaluation and scenario analyses. Socioeconomic aspects are included in the choice of land utilisation type (LUT), i.e. current and potential land use including management of land. The scenario maps provided support in discussions between stakeholders (particularly the farmers, the village leaders and local researchers and authorities) in the PA procedure. Since we dealt with a participatory approach, possible potential land uses had to be weighed against the opinions/possibilities/constraints of the land users. Frequently, it will be necessary to adapt, not the best solution, but merely the most practical solution for the local people even though this may mean less than adequate erosion control (Purnell, 1986). For example, a land unit may be marginally suitable for cropping and highly suitable for forest, but still in the end it may have to be used for cropping due to lack of cropland, provided that the existing cropping cannot be intensified so that marginal land can be used for purposes other than cropping, or that the land users can be subsidised to protect land from degradation.

The objective of this article is to present considerations taken in the choice of critical land properties (land qualities and land characteristics) which were included in the land suitability evaluation and scenario analyses in the project area. Special consideration is given to criteria for agricultural cropland, since one of the crucial points is the potential of reducing arable cropping on sloping land, especially on the steepest areas. Application of the results from this study are found in other articles in this issue (Chen et al., 2003; Hessel et al., 2003).

\section{Materials and methods}

\subsection{Study area}

The study area, Danangou catchment $\left(36^{\circ} 56^{\prime} \mathrm{N}, 109^{\circ} 17^{\prime} \mathrm{E}\right)$, is located in the central area of the Loess Plateau in the northern part of Shaanxi Province in China. It is approximately $5 \mathrm{~km}$ to the north of Ansai, on the western side of the Yanhe river. The catchment covers an area of $3.5 \mathrm{~km}^{2}$ and encompasses two villages, Leipingta and Danangou, with approximately 25 families in each, most of them dependent on subsistence agriculture. Some farmers get part of their income from off-farm work (Hoang Fagerström et al., 2003). There are big altitude differences in the catchment, with several sub-watersheds. The lowest part is situated at the outlet of the catchment at $1085 \mathrm{~m}$ above sea level and the highest hilltop reaches $1370 \mathrm{~m}$. The land use in 1998 consisted of: arable cropland on $37 \%$ of the total catchment area, fallow $(7 \%)$, orchard $(2-3 \%)$, woodland (12\%), shrubland (1-2\%) and wild grassland $(40 \%)$ (Chen at al., 2003). The region has a semi-arid continental climate with an average annual rainfall of $513 \mathrm{~mm}$ (Ansai climate station 1971-1998). The hilly area of the Loess Plateau of China has a very high rate of erosion, averaging $3720 \mathrm{t} \mathrm{km}^{-2}$ year ${ }^{-1}$ (Liu, 1999). Most of the soil loss occurs as a result of a few rainstorms that occur between June and September, during the vegetation period for arable crops. One significant reason for the soil erosion and associated degradation (e.g. nutrient loss) is the intensive cultivation of the sloping land $(\mathrm{Fu}, 1989)$. 


\subsection{Land qualities, land characteristics and available data}

A synopsis of relevant land qualities and characteristics, chosen from results obtained in the project in 1998, is presented in Table 1. The characteristics are grouped according to the quality to which they primarily belong. However, each characteristic can be coupled to several qualities, e.g. 'slope gradient' has an influence on all qualities. Furthermore, a land quality may also be a land characteristic, e.g. 'slope aspect' can be a land characteristic of the land quality 'available water'. In the following, land qualities and characteristics will be called land properties. Data origin for each of the properties is given in the following, combined with interpretation of the results and how it affects the choice of limiting land properties in the area to be used in suitability and scenario analyses (the latter being reported in Chen et al., 2003; Hessel et al., 2003; Hoang Fagerström et al., 2003).

The data and other results from 1998 (and some from 1999) for the different land properties which were used for analysis were the following.

\subsubsection{Climate-precipitation/evaporation}

Ansai climate station (located $8 \mathrm{~km}$ south of the catchment) 1971-1998. Yanan climate station (40 km south of the catchment) 1987-1996. Measured precipitation at four sites in the catchment (1998).

\subsubsection{Temporal and spatial variability of water content in soil}

Measured soil moisture contents with time domain reflectancy equipment (TDR). Soil water contents $(\theta)$ were recorded every second week from the end of May to the

Table 1

Basic available information/data (land characteristics) and their relationships with relevant land qualities

\begin{tabular}{ll}
\hline Land qualities & Land characteristics \\
\hline Available water & $\begin{array}{l}\text { Climate-precipitation/evaporation } \\
\text { Temporal and spatial variability of } \\
\text { water content in soil } \\
\text { Available water storage capacity in soil } \\
\text { Root depth/depth to limiting soil layer }\end{array}$ \\
Slope aspect & Direction in degree in relation to north \\
Soil workability & Soil tillage constraints and clay content \\
Erosion hazard & $\begin{array}{l}\text { Slope gradient } \\
\text { Infiltration capacity, internal drainage/ } \\
\text { limiting layers for water percolation }\end{array}$ \\
Available nutrients & $\begin{array}{l}\text { Phosphorous } \\
\text { Nitrogen } \\
\text { Organic matter } \\
\text { pH }\end{array}$ \\
\hline
\end{tabular}


beginning of October at 17 sites with varying land use and at five depths $(0,10,20,40$ and $80 \mathrm{~cm}$ ). Furthermore, transects with two to three sites along three slopes were chosen.

\subsubsection{Available water storage capacity (AWSC) in soil}

Measured soil water retention characteristics $(\mathrm{pF})$. Soil cores were sampled in the topsoil from 11 locations for different land use and topographies. Soil water contents $(\theta)$ at different supply soil water pressure heads $(\psi)$ were determined with the wind evaporation method in the laboratory (Stolte et al., 1994). Van Genuchten function (van Genuchten, 1980) was fitted to the data points. The AWSC was determined from the difference between $\theta$ at $\psi=-1 \mathrm{~m}$ and $\theta$ at $\psi=-10 \mathrm{~m}$.

\subsubsection{Root depth/depth to limiting soil layer}

Soil profile descriptions (FAO, 1990) to $1 \mathrm{~m}$ depth of 17 sites along two transects in a soil survey. Farmers' view of influence of limiting soil layers on land use in a PA survey 1999. The methods used in the PA survey were social group identification (Buenavista and Flora, 1994), group meetings and village meeting (Pretty, 1995), semistructured interview (Conway and McCracken, 1990), village model (three-dimensional model of the study catchment constructed by the farmers using soil, stones, leaves, etc. as building material) (Conway and McCracken, 1990), landscape transect study in situ (Conway and McCracken, 1990).

\subsubsection{Slope aspect}

Digital elevation map and spatial $\theta$ data, the latter as described in paragraph Temporal and spatial variability of water content in soil above. PA studies (1999) using the same methods as for the property Root depth/depth to limiting soil layer.

\subsubsection{Soil tillage constraints and clay content}

Farmers' criteria in PA survey (1998 and 1999) using the same methods as for the property Slope aspect. Clay content in the soil as resulted from laboratory analyses of samples from the 17 sites of soil profile descriptions (FAO, 1990) along the two transects in the soil survey.

\subsubsection{Slope gradient}

Derived from digital elevation map.

\subsubsection{Infiltration capacity, internal drainage/limiting layers for water percolation}

Measured infiltration capacity in situ and saturated hydraulic conductivities $\left(K_{\mathrm{s}}\right)$ in the laboratory. Soil profile descriptions $(\mathrm{FAO}, 1990)$ to $1 \mathrm{~m}$ depth of the 17 sites along the two transects in the soil survey.

\subsubsection{Phosphorous, nitrogen, organic matter, $\mathrm{pH}$ and soil texture}

On samples from the 17 sites in the soil survey the following data is measured:

- Available phosphorous (P); Olsen method.

- Available nitrogen $(\mathrm{N}) ; \mathrm{NaOH}$ extraction and distilling. 
Table 2

Mean monthly precipitation $(\mathrm{mm})$ and temperature $\left({ }^{\circ} \mathrm{C}\right)$ at Ansai research station $1971-1998$

\begin{tabular}{|c|c|c|c|c|c|c|c|c|c|c|c|c|c|}
\hline & January & February & March & April & May & June & July & August & September & October & November & December & $\begin{array}{l}\text { January- } \\
\text { December }\end{array}$ \\
\hline \multicolumn{14}{|c|}{ Precipitation } \\
\hline Average & 3.5 & 6.1 & 15.1 & 25.5 & 40.4 & 62.5 & 116.4 & 117.2 & 76.1 & 33.3 & 12.0 & 4.9 & 513.0 \\
\hline Min & 0.0 & 0.0 & 0.8 & 3.5 & 3.8 & 6.5 & 24.0 & 21.1 & 2.7 & 7.4 & 0.0 & 0.0 & 275.0 \\
\hline Max & 16.7 & 33.2 & 46.7 & 68.8 & 136.3 & 177.7 & 247.9 & 264.6 & 227.0 & 78.3 & 41.4 & 34.1 & 668.9 \\
\hline \multicolumn{14}{|c|}{ Temperature } \\
\hline Average & -6.8 & -3.0 & 3.3 & 11.1 & 16.7 & 20.9 & 22.4 & 20.9 & 15.3 & 9.1 & 1.7 & -4.8 & 8.9 \\
\hline Min & -9.8 & -6.8 & 0.2 & 9.1 & 15.2 & 19.9 & 21.2 & 19.2 & 14.0 & 6.7 & -1.0 & -8.4 & 8.0 \\
\hline Max & -4.5 & 0.2 & 5.9 & 15.3 & 18.3 & 22.6 & 24.2 & 22.8 & 17.4 & 11.6 & 3.7 & -1.5 & 10.1 \\
\hline
\end{tabular}


Table 3

Mean temperature $\left({ }^{\circ} \mathrm{C}\right)$, precipitation $(\mathrm{mm})$, pan evaporation $(\mathrm{mm})$ and water deficiency (mm; precipitation-pan evaporation) at Yanan climate station $1987-1996$

\begin{tabular}{|c|c|c|c|c|c|c|c|c|c|c|c|c|c|}
\hline & January & February & March & April & May & June & July & August & September & October & November & December & $\begin{array}{l}\text { January- } \\
\text { December }\end{array}$ \\
\hline Temperature & -4 & -0.5 & 5 & 12 & 17.5 & 21.5 & 23.5 & 22 & 19 & 11 & 4 & -1.5 & 10.8 \\
\hline Precipitation & 3 & 5 & 20 & 31 & 33 & 70 & 114 & 122 & 53 & 33 & 12 & 2 & 498 \\
\hline Pan evaporation & 31 & 39 & 65 & 93 & 127 & 138 & 146 & 124 & 96 & 65 & 39 & 31 & 994 \\
\hline Water deficiency & -28 & -34 & -45 & -62 & -94 & -68 & -32 & -2 & -43 & -32 & -27 & -29 & -496 \\
\hline
\end{tabular}


- Organic matter (OM); Bremner and Jenkinson $\mathrm{K}_{2} \mathrm{Cr}_{2} \mathrm{O}_{7}$ method.

- $\mathrm{pH}$; soil/water=1:5, mixing for $30 \mathrm{~min}$ by shaking, electrolytic method.

- Soil texture; $1000 \mathrm{ml}$ soil solution made by $30 \mathrm{~g}$ sample dispersed by $\left(\mathrm{NaPO}_{3}\right)_{6}$, then tested by hydrometer.

\subsubsection{Frequency/areas affected by flooding}

Maps, PA survey 1999 using the methods social group identification (Buenavista and Flora, 1994), group meetings and village meeting (Pretty, 1995), semistructured interview (Conway and McCracken, 1990), landscape transect study in situ (Conway and McCracken, 1990), timeline and trend (Conway and McCracken, 1990).

\section{Results and discussion}

\subsection{Climate-precipitation/evaporation}

Ansai (Table 2) has, compared with Yanan (Table 3), similar average monthly precipitation amounts, but slightly lower average temperatures in all months. Pan evaporation data were available at Yanan but not Ansai. Due to the lower temperatures, the potential evaporation in Ansai is supposed to be slightly lower than at Yanan, but not to a significant extent. There is a water deficiency (precipitation minus pan evaporation) every month (Table 3$)$. During the vegetation period $\left(>5{ }^{\circ} \mathrm{C}\right.$ daily mean temperature), April to October, an average water deficiency of $333 \mathrm{~mm}$ is noted. The project catchment does not meet the optimum demands concerning climatic requirements of common agricultural crops grown in the area (during vegetation period $16-30{ }^{\circ} \mathrm{C}$ temperature and 500-800 $\mathrm{mm}$ precipitation) (FAO, 1994). Generally, with the exception of extremely dry years, it meets the minimum requirements $\left(5-15^{\circ} \mathrm{C}\right.$ and $\left.125-400 \mathrm{~mm}\right)$. For many vegetables, grass species and fruit trees, irrigation or water harvesting is necessary. The water, thus, is a very important limiting property in the area.

During the measurement season (May-September), there was in total on average 67 $\mathrm{mm}$ more rain in the catchment than normal (more in May and July, less in the other months) (Table 4). The deviation of the total precipitation of the four rain gauges from the total average $(479 \mathrm{~mm})$ was only $0.6-6.9 \%$. The monthly values could vary $6-13 \%$ between the gauges but there was no consistent pattern observed in ranked amount between months. More years of measurements are needed to assess any pattern of the spatial distribution of rainfall to a larger degree of certainty. The spatial variability of evaporative demand is further discussed under the following Section 3.2.

\subsection{Temporal and spatial variability of water content in soil and slope aspect}

The soil water content $(\theta)$ values varied during the season in response to the precipitation periods at the 17 sites. In May and first half of June, they approximately varied between $10-25 \%$ in topsoil $(0,10$ and $20 \mathrm{~cm}$ depth) and $10-30 \%$ in subsoil (40 and $80 \mathrm{~cm}$ depth). During the rest of the season (till mid-September), they varied between $5-20 \%$ in topsoil and $5-25 \%$ in subsoil. There was a trend that $\min \theta$ and $\max \theta$ were 
Table 4

Precipitation (mm) in the catchment rain gauges, 7 May-1 October 1998

\begin{tabular}{lrrrrrr}
\hline & May & June & July & August & September & Total \\
\hline A & 136 & 47 & 190 & 81 & 52 & 506 \\
B & 130 & 42 & 178 & 75 & 51 & 476 \\
C & 138 & 45 & 175 & 74 & 53 & 485 \\
D & 112 & 45 & 165 & 74 & 50 & 446 \\
Average & 129 & 45 & 177 & 76 & 52 & 479 \\
Average minus Ansai (Table 2) average & +89 & -18 & +61 & -41 & -24 & +67 \\
\hline
\end{tabular}

larger in the subsoil than in the topsoil (Table 5). Crops on terraces had higher average, $\min$ and $\max \theta$ than the other land use types, probably because more water infiltrates and less water runs off these relatively flat sites during rain events. Wasteland and fallow had smaller $\theta$ ranges in the lower topsoil and subsoil compared with the other land uses, maybe due to that the relatively sparse vegetation at these sites transpires less so that soil water content fluctuates less during the vegetation period. There was a trend for larger $\theta$ values in loessial soils below 1200-1225 m altitude (see Section 3.3 for explanation of this altitude boundary) than above, even though these differences were not significant $(P<0.05)$. The $\theta$-slope transect relationships were very weak. There was a tendency for $\theta$ to increase down the slope, although this was significant $(P<0.05)$ only in 3 out of 14 occasions.

The $\theta$-slope aspect relationships, however, showed a significant pattern $(P<0.05)$ (Table 6). It was observed that the south-facing sites had their $\theta$ ranges at lower values than the north-facing sites. This was probably due to higher evaporative demands and potential increase in the transpirative component due to light/crop growth differences on south-facing sites with subsequent higher potential water consumption rates by crops and

Table 5

Average soil water content $(\theta)(\%)$ based on 10 measurement occasions from May to October, grouped by land use, in topsoil $(0,10$ and $20 \mathrm{~cm}$ depth) and subsoil $(40$ and $80 \mathrm{~cm})$

\begin{tabular}{llllrl}
\hline & Depth & $\begin{array}{l}\text { Number of } \\
\text { observations at } \\
\text { each time step }\end{array}$ & Average (\%) & Min (\%) & Max (\%) \\
\hline Crop/terrace & Topsoil & 6 & 17.2 & 7.9 & 39.3 \\
Crop & Subsoil & 4 & 23.8 & 15.0 & 53.6 \\
& Topsoil & 18 & 13.6 & 3.8 & 28.0 \\
Fallow & Subsoil & 12 & 17.2 & 4.3 & 30.9 \\
& Topsoil & 6 & 11.3 & 5.0 & 19.2 \\
Orchard & Subsoil & 4 & 15.9 & 9.4 & 23.6 \\
\multirow{3}{*}{ Wood } & Topsoil & 6 & 15.2 & 4.7 & 25.9 \\
\multirow{3}{*}{ Shrub } & Subsoil & 4 & 16.3 & 3.5 & 26.5 \\
& Topsoil & 6 & 14.0 & 4.0 & 27.5 \\
Waste & Subsoil & 4 & 15.1 & 3.2 & 34.8 \\
& Topsoil & 3 & 13.0 & 4.0 & 29.3 \\
\hline
\end{tabular}


Table 6

Average $\theta(\%)$ based on 10 measurement occasions from June to October, by slope aspect $(\mathrm{S}=$ south, $\mathrm{N}=$ north), and probability of difference ( $T$-test) between slope aspects by depth

\begin{tabular}{|c|c|c|c|c|c|c|}
\hline $\begin{array}{l}\text { Depth } \\
(\mathrm{cm})\end{array}$ & Aspect & $\begin{array}{l}\text { Number of } \\
\text { observations }\end{array}$ & $\begin{array}{l}\text { Average } \\
(\%)\end{array}$ & $\begin{array}{l}\text { Min } \\
(\%)\end{array}$ & $\begin{array}{l}\text { Max } \\
(\%)\end{array}$ & $\begin{array}{l}P \text {-value } \\
(\%)\end{array}$ \\
\hline \multirow[t]{2}{*}{0} & $\mathrm{~S}$ & 7 & 10.6 & 1.8 & 26.5 & \\
\hline & $\mathrm{N}$ & 10 & 14.2 & 1.6 & 33.0 & 0.0183 \\
\hline \multirow[t]{2}{*}{10} & $\mathrm{~S}$ & 7 & 11.3 & 3.5 & 24.1 & \\
\hline & $\mathrm{N}$ & 10 & 15.4 & 3.9 & 39.6 & 0.0070 \\
\hline \multirow[t]{2}{*}{20} & $\mathrm{~S}$ & 7 & 12.1 & 4.0 & 26.2 & \\
\hline & $\mathrm{N}$ & 10 & 17.0 & 4.1 & 45.4 & 0.0068 \\
\hline \multirow[t]{2}{*}{40} & $\mathrm{~S}$ & 7 & 13.3 & 3.4 & 26.3 & \\
\hline & $\mathrm{N}$ & 10 & 17.9 & 4.4 & 46.0 & 0.0256 \\
\hline \multirow[t]{2}{*}{80} & $\mathrm{~S}$ & 7 & 13.7 & 0.7 & 24.4 & \\
\hline & $\mathrm{N}$ & 10 & 20.2 & 3.5 & 61.2 & 0.0120 \\
\hline
\end{tabular}

trees during the season. For both crops and fruit trees, farmers pointed out that the southfacing slopes in general are better since more light and higher temperatures generate higher yields. However, in dry years, the more shaded north-facing slopes are better since more water is conserved there. The year 1998 was regarded by the farmers a "good" year for crops, with satisfactory amounts of rain. Roughly $50 \%$ of years are assumed to be "good" and 50\% "bad". Therefore, for food security reasons, both sides have to be planted with most crops and fruit tree species needed for the household economies. This should apply also to other rainfed land uses, such as grass and timber trees.

3.3. Available water storage capacity in soil, root depth/depth to limiting soil layer, soil tillage constraints and clay content

By analysing the van Genuchten parameters (van Genuchten, 1980) (Table 7), it was found that there was generally a steep gradient in the $\theta-\psi$ relationship in the $\mathrm{pF}$ curves (i.e. a large amount of equivalent pores of specific diameter) between soil water pressure

Table 7

Van Genuchten parameters as derived from water retention analyses of soil cores

\begin{tabular}{lllllll}
\hline & Replicate & $\theta_{\mathrm{r}}$ & $\theta_{\mathrm{s}}$ & $\alpha$ & $n$ & $m$ \\
\hline Crop 1 & 1 & 0.075 & 0.325 & 0.0120 & 1.797 & 0.443 \\
Crop 1 & 2 & 0.050 & 0.300 & 0.0100 & 1.615 & 0.381 \\
Crop 2 & 1 & 0.120 & 0.425 & 0.0075 & 1.925 & 0.481 \\
Crop 2 & 2 & 0.100 & 0.435 & 0.0078 & 2.190 & 0.543 \\
Orchard & 1 & 0.100 & 0.466 & 0.0049 & 2.497 & 0.600 \\
Orchard & 2 & 0.100 & 0.459 & 0.0052 & 2.700 & 0.630 \\
Woodland & 1 & 0.100 & 0.450 & 0.0036 & 3.058 & 0.673 \\
Woodland & 2 & 0.100 & 0.408 & 0.0054 & 2.953 & 0.661 \\
Shrubland & 1 & 0.100 & 0.350 & 0.0062 & 3.207 & 0.688 \\
Wasteland & 1 & 0.100 & 0.320 & 0.0067 & 3.310 & 0.698 \\
Wasteland & 2 & 0.100 & 0.391 & 0.0067 & 2.331 & 0.571 \\
\hline
\end{tabular}


head $(\psi)=-1 \mathrm{~m}(=0.03 \mathrm{~mm}$ pore diameter $)$ and $\psi=-10 \mathrm{~m}(=0.003 \mathrm{~mm}$ pore diameter $)$. In practice, this means that the amount of rain falling during the season is critical. If $\psi$ is kept above $-10 \mathrm{~m}$ in the soil, the water status may be good. This $\psi$ corresponded to $\theta$ values of $10-16 \%$. During the period mid-June to September, field measured $\theta$ varied between $5 \%$ and $10 \%$ in the uppermost $0-20 \mathrm{~cm}$ at approximately $50 \%$ of the sites (most other sites having values $10-20 \%$ ). Below this depth, however, $\theta$ varied in the range 10 $20 \%$ at most sites.

From five sites with measurements of both laboratory determined $\theta-\psi$ relationships and field determined $\theta$, the upper limit for the AWSC $(\psi=-1 \mathrm{~m})$ ranged between $28 \%$ and $43 \%$, whereas the range of max field $\theta$ was $21-31 \%$ (Table 8 ), possibly implying that for the cropland, orchard and woodland sites, the whole potential of AWSC was not exploited. An ASWC range of $18-31 \%$ was realised for the sites and a field $\theta$ range of 15-28\%. Compared with values of AWSC found in other soils (Landon, 1991), these are very high.

A litho-/pedological map compiled and digitalized within the framework of the project identified five classes in the catchment (based on delineation of the appearance on the land surface) (Messing et al., 2003) (also Fig. 1): (i) yellow loess (75\% of the catchment area) in middle and upper parts of the hillslopes and on hill ridges/tops, (ii) red loess and red clay (15\%) in lower parts of hillslopes, (iii) alluvial material (1\%) in gully bottoms, (iv) weathered bedrock (3\%) on steep eroded slopes, (v) bedrock $(6 \%)$ on steep eroded slopes and in gully bottoms. The restricted root depths in the catchment area were in the soil survey found to be in accordance with Table 9, where grade $1=>100 \mathrm{~cm}$, grade $2=80-100 \mathrm{~cm}$, grade $3=50-80 \mathrm{~cm}$, grade $4=20-50 \mathrm{~cm}$, grade $5=<20 \mathrm{~cm}$. Some of the soils, where layers of a soil type locally named Huangjiaotu lies close to or at the soil surface, can become so hard as to somewhat impede both tillage and root penetration. This type of layer was found to occur in loess soils below 1200-1225 m altitude. The reason for the properties of this soil type may be an effect of pedological and other processes in the past causing more or less cemented layers in the stratification (Lin and Liang, 1982; Liu et al., 1985), or found in the proportions of sand/ silt/clay. The clay contents ranged between $11-29 \%$ below $1200-1225 \mathrm{~m}$ and $14-19 \%$ above 1200-1225 m, thus having a wider range in the former case. In an alluvial soil, clay content ranged between $18 \%$ and $26 \%$ in different layers. In alluvial, weathered bedrock and bedrock units, the root depth was restricted by gravel/stones and depth to solid bedrock.

Table 8

Comparison of actual soil water contents in field $(\theta)$ and AWSC determined from pF curves in topsoil

\begin{tabular}{|c|c|c|c|c|c|c|}
\hline & \multicolumn{3}{|c|}{ Field $\theta$ at $0-10 \mathrm{~cm}$ depth $(\%)$} & \multicolumn{3}{|c|}{$\mathrm{pF} \theta$ at $0-10 \mathrm{~cm}$ depth $(\%)$} \\
\hline & Max & Min & Range & $\psi=-1 \mathrm{~m}$ & $\psi=-10 \mathrm{~m}$ & AWSC \\
\hline Cropland & 27 & 7 & 20 & 36 & 16 & 20 \\
\hline Orchard & 21 & 5 & 16 & 42 & 12 & 30 \\
\hline Woodland & 28 & 13 & 15 & 43 & 12 & 31 \\
\hline Shrubland & 31 & 3 & 28 & 32 & 10 & 22 \\
\hline Wasteland & 25 & 6 & 19 & 28 & 10 & 18 \\
\hline
\end{tabular}




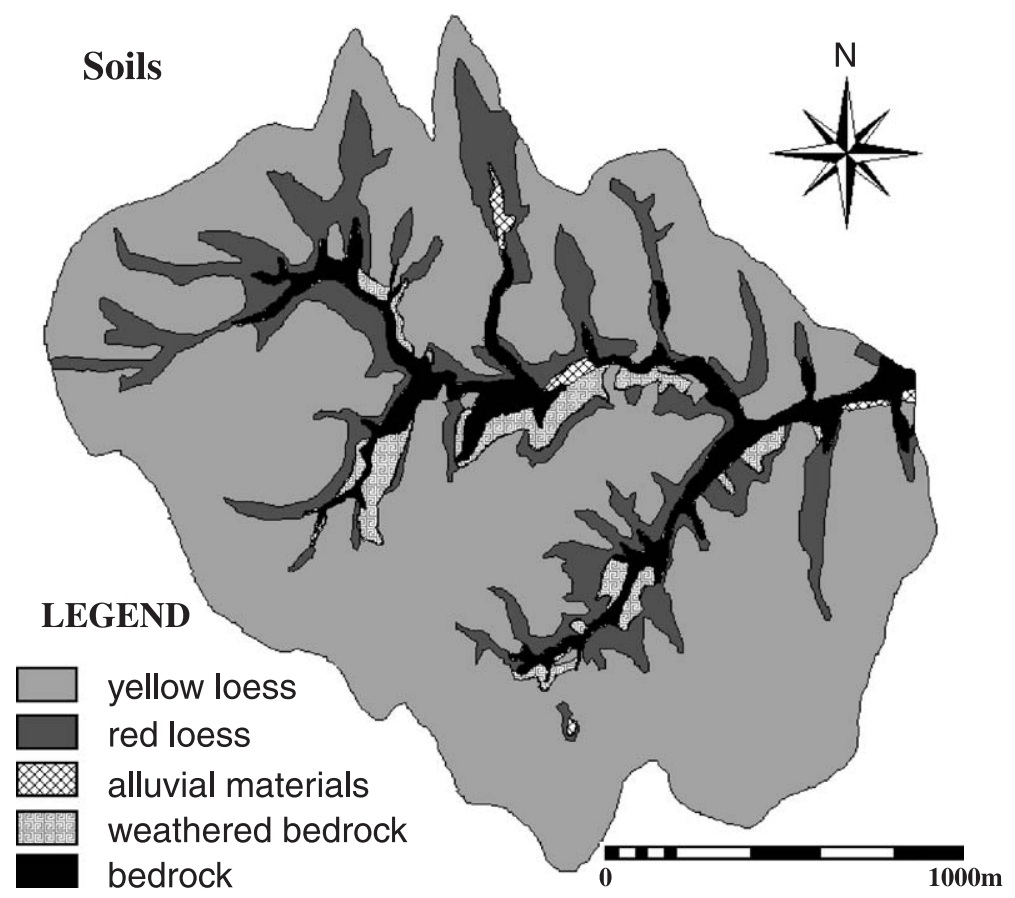

Fig. 1. Soil type classes in the study area.

Farmers in the project area pointed out the occurrence of these restrictions particularly from the point of view of soil workability. They reported the occurrence of soils that were hard to cultivate or with hard layers close to the soil surface. They were to be found on the

Table 9

Restriction for root depth

\begin{tabular}{|c|c|}
\hline Soil type & Restrictions \\
\hline $\begin{array}{l}\text { In yellowish loessial soils in the higher part of the } \\
\text { catchment (above } 1200-1225 \mathrm{~m} \text { altitude) and } \\
\text { predominantly in soils with the local name Huangtu }\end{array}$ & No or very slight (grades $1-2$ ) \\
\hline $\begin{array}{l}\text { In yellowish loessial soils in the lower part of the } \\
\text { catchment (below } 1200-1225 \mathrm{~m} \text { altitude) and } \\
\text { predominantly in soils with layers of Huangjiaotu } \\
\text { (yellow clayish) }\end{array}$ & $\begin{array}{l}\text { Slight (grades } 2-3 \text { ): workability, } \\
\text { root depth (Huangjiaotu layers) }\end{array}$ \\
\hline In alluvial soils of main gully bottoms & $\begin{array}{l}\text { Slight (grades 2-3): root depth } \\
\text { (gravel layers) }\end{array}$ \\
\hline Red loessial soils and layers of Hongjiaotu (red clayish) & $\begin{array}{l}\text { Moderate (grades } 3-4 \text { ): workability, } \\
\text { root depth (Hongjiaotu layers) }\end{array}$ \\
\hline Weathered bedrock (including soil material) & $\begin{array}{l}\text { Severe (grades } 4-5 \text { ): workability, } \\
\text { root depth (bedrock closely underneath) }\end{array}$ \\
\hline Bedrock (including soil material) & $\begin{array}{l}\text { Severe (grades } 4-5) \text { : workability, } \\
\text { root depth (bedrock) }\end{array}$ \\
\hline
\end{tabular}


Table 10

Interpretation of slope gradient and proportion of slope gradients in the project catchment

\begin{tabular}{llcc}
\hline & Slope degree & Area $\left(\mathrm{m}^{2}\right)$ & $\begin{array}{l}\text { Portion of the } \\
\text { whole catchment }(\%)\end{array}$ \\
\hline Flat & $<3$ & 58,500 & 1.7 \\
Gently sloping & $3-8$ & 102,150 & 2.9 \\
Moderately sloping & $8-15$ & 355,800 & 10.2 \\
Strongly sloping & $15-25$ & 789,275 & 22.6 \\
Steep to very steep & $>25$ & $2,190,075$ & 62.6 \\
\hline
\end{tabular}

midslopes and attributed to yellow clayish soil layers (Huangjiaotu) below the soil surface. It was possible to keep the top layer porous by tillage activities. Every year, however, some topsoil was lost by water erosion, and in some years, when heavy rainstorms occurred, the whole loose top layer was lost. Then a new loose topsoil had to be worked up from the hard subsoil. This hard layer was considered not to restrict root depth if wetted, but could during drying up constitute a restriction. There were hard tillage layers (difficult to plough) also at some sites with the red clayey soil (Hongjiaotu). The reason that these soil layers appeared in the soil surface may be erosion. Other disturbing features were, according to the farmers, many small stones in the soil and in some places big stones occurred in the soil.

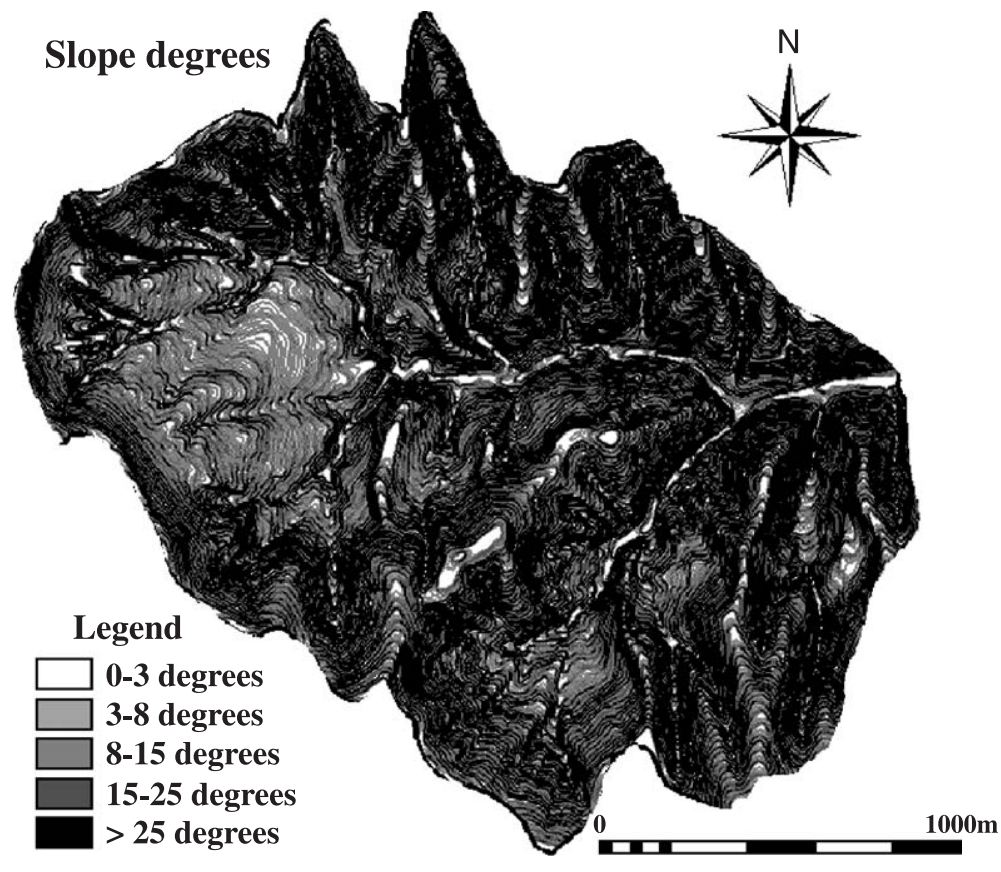

Fig. 2. Slope degree classes in the study area. 


\subsection{Slope gradient, infiltration capacity, internal drainage/limiting layers for water per- colation}

Slope gradient was considered to be one of the main properties critical for the extent of water runoff and erosion in the study catchment. More than $60 \%$ of the catchment is steeper than $25^{\circ}$ (Table 10, Fig. 2). If, for example, merely land with slopes $<15^{\circ}$ are to be used for cropland (including fallow), then only $15 \%$ of catchment would be suitable. At the time of the study, as much as $45 \%$ of the catchment was used for cropland/fallow. The infiltration potential into the soil is generally decreasing with increasing slope gradient (Hudson, 1995). If horizons in or just below the soil surface are slowly permeable, water runoff generation can occur at an earlier stage on the soil surface and/or water can percolate laterally down the slope in the horizon above the limiting layer (Ritsema et al., 1996). In rainfall simulation experiments in the project catchment, the stable infiltration rate was found to be related to slope gradient. Thus, as slope degree increased from 5 to 30 , the time spell before runoff generation decreased from 8.7 to $4.3 \mathrm{~min}$ and stable infiltration rate from 2.5 to $1.1 \mathrm{~cm} \mathrm{~h}^{-1}$. The range of measured values of saturated hydraulic conductivity $\left(K_{\mathrm{s}}\right)$ in the project catchment is presented together with an interpretation of $K_{\mathrm{s}}$ in Table 11. Most of the land used for cropping had good permeability (moderately rapid to very rapid $K_{\mathrm{s}}$ ). On soils with slow to moderately slow $K_{\mathrm{s}}$, some inhibition of water may take place. Larger $K_{\mathrm{s}}$ was found in topsoil than subsoil in the "bottom" and "middle" slope sites. The lower $K_{\mathrm{s}}$ values in the subsoil relate to horizons with reduced permeability, like layers of Huangjiaotu and Hongjiaotu as described in Section 3.3.

Table 11

Interpretation of saturated hydraulic conductivity $\left(K_{\mathrm{S}}\right)(\mathrm{FAO}, 1990)$ and its relation to the results in the project catchment

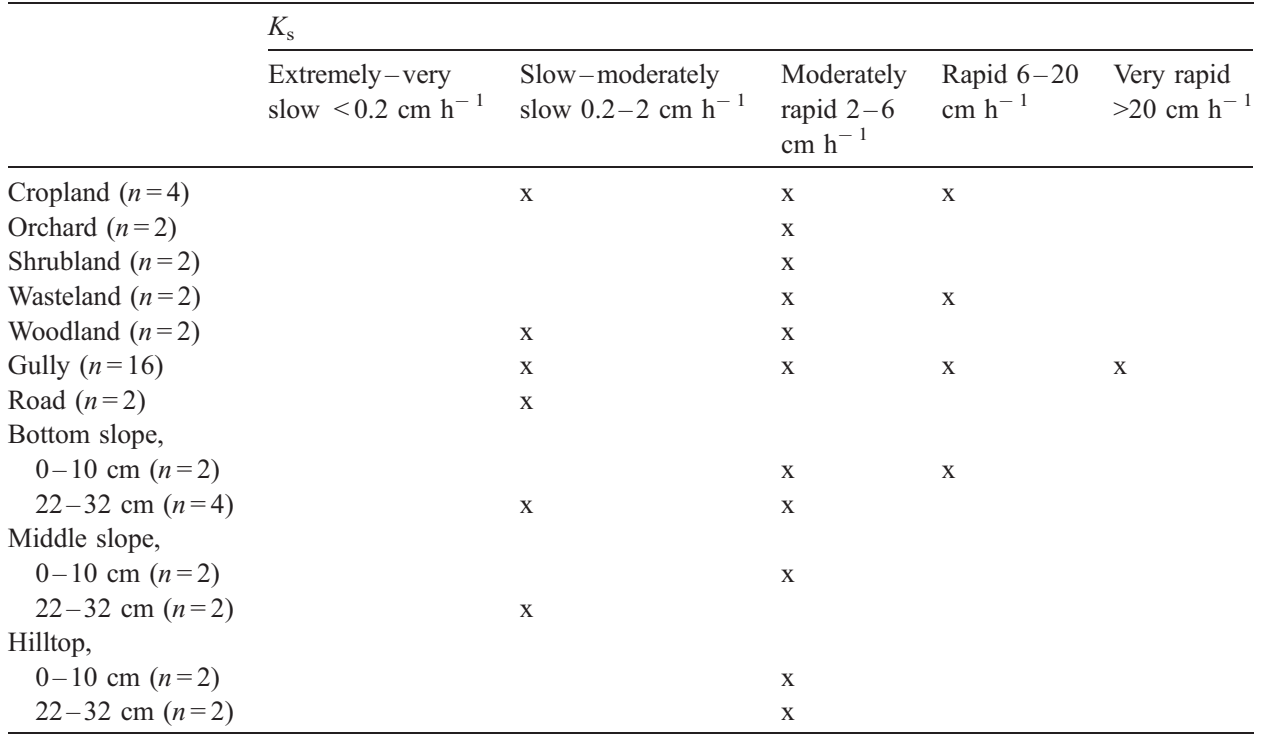




\subsection{Phosphorous, nitrogen, organic matter, $\mathrm{pH}$ and soil texture}

At the 17 sites studied, larger average available $\mathrm{P}, \mathrm{N}$ and $\mathrm{OM}$ were found in the uppermost horizons than in the underlying ones (Table 12). The $\mathrm{pH}$ is very high in all horizons (>8.7) and the soil texture is silt loam for all soils, but with varying proportions of sand/silt/clay. Gravel only occurred at three of the sites: $4.3-58.1 \%$ of total soil mass in a stratified alluvial deposit (formed behind a former check-dam), $90 \%$ at $82 \mathrm{~cm}$ depth in a reddish loessial soil (transition layer to bedrock) and $2.4-9.9 \%$ in material from a land slide on a steep slope. In comparison with international tables of crop nutrient demand (Landon, 1991), the catchment values of $\mathrm{pH}$ are very large and those of $\mathrm{P}, \mathrm{N}$ and $\mathrm{OM}$ are very small. Applying grading of parameters to the soils of the 17 sites (59 horizons) reveals that for $\mathrm{N}, \mathrm{OM}$ and $\mathrm{pH}$ all horizons fell within the lowest interpretation grades (Landon, 1991). For P, 54 of the horizons fell within the lowest grades, 2 within intermediate grade and only 3 within the highest grade (for common crops).

It was observed that average values (and ranges) of available $\mathrm{P}$, available $\mathrm{N}$ and $\mathrm{OM}$ tend to be smaller in the loessial soils above an altitude of 1200-1225 than below the same. This could partly be explained by the fact that average clay content is smaller above $1200-1225 \mathrm{~m}$. The site with alluvial soil at an altitude of $1110 \mathrm{~m}$, however, had the same average and range of nutrient values as the loessial soils above $1200-1225 \mathrm{~m}$. It was also noticed that available $\mathrm{P}$ was higher in fields close to the farms on loessial soils where $\mathrm{P}$ fertilisation had been performed, especially so on the slopes just southwest of Leipingta. Total $\mathrm{P}$ did not vary much between the sites, so $\mathrm{P}$ availability is exclusively related to its external inputs. The contents of $\mathrm{OM}$ and $\mathrm{N}$ (being correlated to each other; $r=0.90$ ) were also somewhat correlated to land use management, larger values being found in the topsoil of woodland (whereas P-values were lower). On cropland, on the other hand, OM and N values tended to be lower than in woodland. Therefore, soil conservation measures, which bring about reduction in nutrient losses caused by erosion, and a choice of land use management, which brings organic matter back to the soil, e.g. soil mulching, can improve the $\mathrm{N}$ status. Even with measures taken to improve the $\mathrm{P}$ and $\mathrm{N}$ status, the soils still suffer from the very large $\mathrm{pH}$ values (there was a trend for smaller $\mathrm{N}$ and $\mathrm{P}$ availability with larger values of $\mathrm{pH}$ ), which bring about decreasing availability of nutrients for the crops (Landon, 1991). Of the sites in the study, $\mathrm{pH}$ was somewhat lower on soils, which were

Table 12

Average, min and max values of nutrient parameters in uppermost horizon (Upp) $(n=17)$ and underlying horizons (Und) $(n=42)$

\begin{tabular}{|c|c|c|c|c|c|c|c|c|}
\hline & Horizon & $\begin{array}{l}\text { Available P } \\
\left(\mathrm{mg} \mathrm{kg}^{-1}\right)\end{array}$ & $\begin{array}{l}\text { Available } \mathrm{N} \\
\left(\mathrm{mg} 100 \mathrm{~g}^{-1}\right)\end{array}$ & $\begin{array}{l}\text { Organic } \\
\text { matter }(\%)\end{array}$ & $\mathrm{pH}$ & $\begin{array}{l}\text { Sand } \\
(\%)\end{array}$ & $\begin{array}{l}\text { Silt } \\
(\%)\end{array}$ & $\begin{array}{l}\text { Clay } \\
(\%)\end{array}$ \\
\hline \multirow[t]{2}{*}{ Average } & Upp & 2.1 & 2.8 & 0.65 & 8.84 & 14.4 & 67.0 & 18.6 \\
\hline & Und & 1.7 & 1.5 & 0.33 & 8.92 & 13.7 & 67.1 & 19.1 \\
\hline \multirow[t]{2}{*}{ Min } & Upp & 0.1 & 0.9 & 0.19 & 8.70 & 9.5 & 59.7 & 11.1 \\
\hline & Und & 0.1 & 0.5 & 0.11 & 8.75 & 6.5 & 53.5 & 11.6 \\
\hline \multirow[t]{2}{*}{ Max } & Upp & 8.4 & 5.6 & 1.32 & 9.27 & 20.0 & 74.5 & 26.2 \\
\hline & Und & 11.3 & 3.2 & 0.74 & 9.22 & 30.0 & 73.7 & 29.0 \\
\hline
\end{tabular}


predominantly used for crop/fallow, possibly implying that cropping activities can lower the $\mathrm{pH}$.

\subsection{Frequency/areas affected by flooding}

This property mainly affects the alluvial and bedrock soils at the bottom of the gullies. One impact of the flooding was exemplified by a large dam constructed of soil in the main gully in 1972. A 5-m-thick layer of sediment was trapped behind the dam until it broke down in 1975. At the time of the study, the sediments along the central gully furrow had been swept away by water whereas some of the sediments along the sides of the gully remained and were used for cropping. It is considered important that before structures, like dams, are constructed in the lower part of the catchment, the higher parts have to be treated in a way that reduces the intensity of surface water runoff (FAO, 1979), or else the lower structures may break in the heavy rainstorms which occasionally occur. In the timeline analysis in group meetings with the farmers, it was found that that serious floods occurred at approximate intervals of 3-10 years $(1975,1985,1988,1993$ and 1998). It was considered that crops on alluvial soils were badly damaged only in 1 year out of 10. This frequency is interpreted as rare or very rare (FAO, 1983). It was furthermore obvious that farmers did not consider the flooding hazard as a major threat since some of them were eager to increase the area of alluvial soils by constructing dams on the gully bottoms.

\subsection{Land utilisation types}

An important factor required in the FAO framework approach is the definition of land utilisation type (FAO, 1976). A classification of LUT, adapted from the results of a survey in 1998, identified three categories (Carlsson, 2000) (Table 13). The category A was characterised by land users having a low input of fertilisers and only a small part of the harvest was produced for the market. The category B spanned in terms of wealth from households where income from off-farm jobs constituted a moderate contribution, to the most wealthy household. More fertilisers were used than in category A, but in many cases this was applied on a smaller part of the cropland. The category $\mathrm{C}$ had the production based on grazing animals (mainly goats). Very few farm families belonged to this category. Furthermore, grazing has been prohibited in the catchment since 1999. The suitability evaluation in this project, therefore, was based on the majority of farmers, found in type A and to a certain extent in type B. With the LUT characteristics at the time of the study, ample artificial fertilisation could not be afforded by a majority of the land users. Measures to increase the organic matter content in the soil, and thereby protect it from being eroded away with the water, was one straightforward way to improve nutrient availability. The means of improving the water and nutrient status had to be acceptable to the farmers, in view of, e.g., inputs of money and labour. So, for example, terracing could be the most effective way to reduce erosion and improve the water status in the soil. However, it would demand a large input in the form of either money or labour. From a socioeconomic aspect, therefore, the incorporation of grass strips (Lu and Stocking, 2000) and/or crop/ improved fallow rotation in the land management may be a more sustainable solution than terracing. 
Table 13

Land utilisation types (LUT) (Carlsson, 2000)

\begin{tabular}{|c|c|c|c|}
\hline & A & $\mathrm{B}$ & $\mathrm{C}$ \\
\hline Type of production & $\begin{array}{l}\text { Subsistence, smaller part sold on } \\
\text { local market and to government. }\end{array}$ & Subsistence, larger part sold to local market. & Production for market. \\
\hline $\begin{array}{l}\text { Structure of } \\
\text { household income }\end{array}$ & $\begin{array}{l}\text { Diverse (from excess produce sold } \\
\text { to the market, vegetables, animal } \\
\text { husbandry and handicraft). }\end{array}$ & Uniform (large part from off-farm jobs). & $\begin{array}{l}\text { Uniform (major part } \\
\text { from selling of animals). }\end{array}$ \\
\hline Crops & $\begin{array}{l}\text { Millet, potatoes, beans and maize. } \\
\text { Limited forestry, vegetable and } \\
\text { fruit production. }\end{array}$ & $\begin{array}{l}\text { Use of improved crop varieties. } \\
\text { A larger share produced for market, } \\
\text { e.g. maize, sunflowers and beans. } \\
\text { Irrigated fruit orchards and forestry. }\end{array}$ & $\begin{array}{l}\text { Millet, potatoes, } \\
\text { beans and maize. }\end{array}$ \\
\hline Animal husbandry & Small-scale for market. & Small-scale for subsistence. & Goat herding. \\
\hline Labour division & $\begin{array}{l}\text { Land preparation by men, other } \\
\text { activities the rest of the family, } \\
\text { mostly by women. }\end{array}$ & $\begin{array}{l}\text { Women and children, relatives or hired } \\
\text { labour. Men involved in preparation of } \\
\text { land and harvest. }\end{array}$ & Men herders. \\
\hline Land management & $\begin{array}{l}\text { Low input of fertilisers, labour } \\
\text { intensive production, utilisation } \\
\text { of all land. }\end{array}$ & $\begin{array}{l}\text { High input of fertilisers, labour extensive } \\
\text { production, steeper land left fallow. }\end{array}$ & $\begin{array}{l}\text { Grazing over large } \\
\text { areas. Responsibilities } \\
\text { to avoid crop damages } \\
\text { due to grazing. }\end{array}$ \\
\hline Land allocation & $\begin{array}{l}\text { Access to share of village land } \\
\text { not subject to contracts. }\end{array}$ & Savings give possibilities to contract land. & $\begin{array}{l}\text { Access to common } \\
\text { land for grazing. }\end{array}$ \\
\hline
\end{tabular}

Capital

Land structure

Infrastructure

Extension

Small possibilities for credits others than from neighbours and relatives.

Small and fragmented plots, no fencing of common land used for grazing.

Poor transportation to much of the cropland with paths in steep terrain and no bridge near village to cross the river.

No extension activities in the area.

Technology used in

Ploughing with mules or cows, harvesting by hand, crops transported on backs (mule or human), limited irrigation used in orchards and

on flat land along the river, labour intensive terrace constructing and repairs, less or no fertiliser on remote land due to poor transportation. 


\section{Conclusions}

The description of LUT chosen for the maps of current suitability evaluation made within the framework of the project was: subsistence, using cropland and to a limited extent forestry, vegetable, fruit trees and animals, with low inputs of fertilisers and small possibilities for credits. Whatever management changes were carried out to improve the productivity and sustainability in the project catchment, restrictions for agricultural production were large. The major constraints were water availability, nutrient availability and erosion hazard.

The number of relevant land qualities and characteristics (as given in Table 1) was reduced in the final choice of criteria for the suitability rating. The results were applied in line with the discussion in the interpretation of available data given in Section 3. Only properties with a significant spatial variability (within the catchment) in ranges of significant influence were chosen. Furthermore, it was applied to the concept of "land quality" as conceived by the farmers, which was much related to the water status and soil tillage constraints. For the suitability rating criteria, the following was considered.

- The precipitation was not taken into account since its cumulative spatial variability in the catchment during the cropping period as a whole was small. More years of measurements are needed to explore this property further. It should be noted, however, that, in years with low precipitation amounts, poor water content values in the soil profile arise.

- Compared with values of the AWSC found in other soils, they are high in this catchment and it was concluded that AWSC was not a limiting property.

- Slope aspect was considered to have a considerable influence (drier on south-facing slopes) on crop production, but since both south-facing and north-facing sides were, alternatively (depending on rain amounts in different years), good for agricultural crops, slope aspect was not included in the criteria. However, in scenario analyses (see Chen et al., 2003; Hessel et al., 2003), consideration was given to slope aspect when defining criteria for grassland and woodland/shrubland.

- Partly due to the very large $\mathrm{pH}$ values on all soils in the catchment, nutrients are available to the plants to a resticted degree. The nominal values of the nutrient properties were very low. For example, most of the available $\mathrm{P}$ and $\mathrm{N}$ values were smaller than in the lowest rated classes in interpretative literature. Furthermore, any spatial variability in the nutrient properties investigated was correlated to land use rather than to inherent properties of the soil. For these reasons, the nutrient status was omitted from the rating criteria and was included just as a background condition.

- It was found that the crops on alluvial soils were, on average, badly damaged by flooding only in 1 year out of 10 . This frequency is interpreted as rare or very rare. Therefore, flooding hazard was not included as a restricting property in this evaluation.

The parameters of importance for further suitability studies were identified: soil type (as related to the properties root depth/depth to limiting soil layer, soil tillage constraints and clay content, infiltration capacity, internal drainage/limiting layers for water percolation) (Fig. 1) and slope gradient (Fig. 2). Reduced depth to limiting layer for root penetration, 
water percolation and soil workability (tillage) were found on the loessial soils below $1200-1225 \mathrm{~m}$. This was assumed to be a slight constraint, but is in the scenario analyses counterbalanced by the fact that the soils below 1200-1225 $\mathrm{m}$ have a somewhat higher clay content and thereby slightly better nutrient conditions, as well as by the proximity of those soils to the villages. Further restrictions are gravel and stone material on alluvial and bedrock soils and on eroded steep slopes with shallow soils and rocky outcrops. The slope gradient is important due to the high proportion of steep slopes in the catchment, $85 \%$ of the catchment area having slopes steeper than $15^{\circ}$.

The results in this article comprise basic material for the maps used in suitability, scenario and modelling analyses in Chen et al. (2003) and Hessel et al. (2003).

\section{Acknowledgements}

This article is presented within the scope of the EU financed project "A Participatory Approach for Soil and Water Conservation Planning, Integrating Soil Erosion Modeling and Land Evaluation, to Improve the Sustainability of Land Use on the Loess Plateau in Northern China-EROCHINA" (Contract Number IC18-CT97-0158). The work has been fulfilled with the excellent cooperation of farmers in the catchment and collegues in this project.

\section{References}

Buenavista, G., Flora, C.B., 1994. Participatory methodologies for analyzing household activities, resources, and benefits. In: Feldstein, H.S., Jiggins, J. (Eds.), Tools for the Field. Methodologies Handbook for Gender Analysis in Agriculture. Kumarian Press, West Hartford, pp. 36-44.

Carlsson, M., 2000. Farmers knowledge in land evaluation - a case study of land suitability in a small catchment affected by erosion on the Chinese Loess Plateau. Minor Field Studies, Swedish University of Agricultural Sciences, International Office, Uppsala, Sweden, vol. 106.

Chen, L., Messing, I., Zhang, S., Fu, B., Ledin, S., 2003. Land use evaluation and scenario analysis towards sustainable planning on the Loess Plateau in China - case study in a small catchment. Catena 54, 303-316. (doi:10.1016/S0341-8162(03)00071-7)

Conway, G.R., McCracken, J.A., 1990. Rapid rural appraisal and agroecosystem analysis. In: Altieri, M.A., Hecht, S.B. (Eds.), Agroecology and Small Farm Development. CRC Press, Florida, pp. 221-235.

Driessen, P.M., Konijn, N.T., 1992. Land-use Systems Analysis. Wageningen Agricultural University, Department of Soil Science and Geology, Wageningen.

FAO, 1976. A framework for land evaluation. Soils Bulletin, vol. 32. Food and Agricultural Organization of the United Nations, Rome.

FAO, 1979. Watershed development with special reference to soil and water conservation. FAO Soils Bulletin, vol. 44. Food and Agricultural Organization of the United Nations, Rome.

FAO, 1983. Guidelines: land evaluation for rainfed agriculture. FAO Soils Bulletin, vol. 52. Food and Agricultural Organization of the United Nations, Rome.

FAO, 1990. Guidelines for Soil Profile Description. Food and Agricultural Organization of the United Nations, Rome.

FAO, 1994. Ecocrop 1-Crop Environmental Requirements Database. Food and Agricultural Organization of the United Nations, Rome.

Fu, B., 1989. Soil erosion risk and its control in the loess plateau of China. Soil Use and Management 5, 76-82. 
Hessel, R., Messing, I., Chen, L., Ritsema, C.J., Stolte, J., 2003. Soil erosion simulations of land use scenarios for a small Loess Plateau catchment. Catena 54, 289-302. (doi:10.1016/S0341-8162(03)00070-5)

Hoang Fagerström, M.H., Messing, I., Wen, Z.M., Trouwborst, K.O., Xu, M.X., Zang, X.P., Olsson, C., Andersson, C., 2003. A participatory approach for integrated conservation planning in a small catchment in Loess Plateau, China: Part II. Analysis and findings. Catena 54, 271-288. (doi:10.1016/S0341-8162(03)00069-9) Hudson, N., 1995. Soil Conservation. BT Batsford, London.

Landon, J.R., 1991. Booker Tropical Soil Manual. Booker Tate, England Copublished: Wiley, New York.

Lin, Z., Liang, W., 1982. Engineering properties and zoning of loess and loess-like soils in China. Canadian Geotechnical Journal 19, 76-91.

Liu, G., 1999. Soil conservation and sustainable agriculture on the Loess Plateau: challenges and prospects. Ambio 28, 663-668.

Liu, T., An, Z., Yuan, B., Han, J., 1985. The loess-paleosol sequence in China and climatic history. Episodes 8, $21-28$.

Lu, Y., Stocking, M., 2000. Integrating biophysical and socio-economic aspects of soil conservation on the Loess Plateu, China: Part III. The benefits of conservation. Land Degradation and Development 11, 153-165.

Messing, I., Chen, L., Hessel, R., 2003. Soil conditions in a small catchment on the Loess Plateau in China. Catena 54, 45-58. (doi:10.1016/S0341-8162(03)00056-0)

Pretty, J.N., 1995. Participatory learning for sustainable agriculture. World Development 23, 1247-1263.

Purnell, M.F., 1986. Application of the FAO framework for land evaluation for conservation and land-use planning in sloping areas; potentials and constraints. In: Siderius, W. (Ed.), Land evaluation for land-use planning and conservation in sloping areas, ILRI publication 40. Proceedings from International Workshop, Enschede, The Netherlands, 17-21 December 1984. International Institute for Land Reclamation and Improvement, Wageningen, The Netherlands, pp. 17-31.

Ritsema, C.J., Oostindie, K., Stolte, J., 1996. Evaluation of vertical and lateral flow through agricultural loessial hillslopes using a two-dimensional computer simulation model. Hydrological Processes 10, 1091-1105.

Stocking, M., Lu, Y., 2000. Integrating biophysical and socio-economic aspects of soil conservation on the Loess Plateu, China: Part I. Design and calibration of model. Land Degradation and Development 11, $125-139$.

Stolte, J., Veerman, G.J., Wopereis, M.C.S., 1994. Measurement of soil hydraulic properties. In: Wopereis, M., Kropff, M., Bouma, J., van Wijk, A., Woodhead, T. (Eds.), Soil Physical Properties: Measurement and Use in Rice-based Cropping Systems. International Rice Research Institute, Manila, Philippines, pp. 5-36.

Van Genuchten, M.T., 1980. A closed-form equation for predicting the hydraulic conductivity of unsaturated soils. Soil Science Society of America Journal 44, 892-898. 